\title{
IMPLEMENTASI PROGRAM PERLINDUNGAN ANAK TERPADU BERBASIS MASYARAKAT DI KOTA PALANGKA RAYA
}

\author{
Implementation of Community-Based Integrated Child Protection Program in Palangka \\ Raya
}

\author{
Mita Sari* \\ Wahyu \\ Bachruddin Ali Achmad
}

Universitas Lambung

Mangkurat, Banjarmasin, South

Kalimantan, Indonesia

*email: mitasyaja@gmail.com

\section{Kata Kunci:}

Implementasi

Program Perlindungan Anak

Terpadu Berbasis Masyarakat

Pemerintah Kota Palangka Raya

Keywords:

Implementation

Community based Integrated

Child Protection Program

Palangka Raya Government

\begin{abstract}
Abstrak
Tujuan dari penelitian ini adalah untuk mengetahui, menjelaskan bagaimana Implementasi Program Perlindungan anak terpadu berbasis masyarakat, serta faktorfaktor yang mendukung dan menghambat program perlindungan anak terpadu berbasis masyarakat. Penelitian ini dilakukan di Dinas Pengendalian Penduduk Dan Keluarga Berencana, Pemberdayaan Perempuan, Perlindungan Anak Kota Palangka Raya dengan menggunakan metode kualitatif. Hasil penelitian ini menunjukkan bahwa Implementasi Program Perlindungan Anak Terpadu Berbasis Masyarakat (PATBM) pada Dinas Pengendalian Penduduk dan Keluarga Berencana, Pemberdayaan Perempuan, Perlindungan Anak Kota Palangka Raya meliputi bahwa Program PATBM telah berjalan dan tepat sasaran, Program PATBM bermanfaat dan diterima di Kota Palangka Raya, selama dilaksanakan Program tersebut telah terjadi penurunan angka kekerasan, Sumber daya Implementasi program PATBM baik dilihat dari sisi sumber daya manusia dan anggaran masih kurang dan belum memadai, Program tersebut mendapatkan respon yang baik dari masyarakat Kota Palangka Raya, serta strategi yang dilakukan oleh Dinas Pengendalian Penduduk dan Keluarga Berencana, Pemberdayaan Perempuan, Perlindungan Anak Kota Palangka Raya dalam mengimplementasi program perlindungan anak terpadu berbasis masyarakat adalah dengan melaksanakan kegiatan sosialisasi dan pelatihan bagi aktivis atau kader PATBM dilingkungan Pemerintah Kota Palangka Raya.
\end{abstract}

\begin{abstract}
The purpose of this study was to find out, explain how the implementation of an integrated community-based child protection program, as well as the factors that support and inhibit integrated community-based child protection programs. This research was conducted at the Department of Population Control and Family Planning, Women's Empowerment, Child Protection in Palangka Raya City using qualitative methods. The results of this study indicate that the Implementation of the Community Based Integrated Child Protection Program (PATBM) in the Department of Population Control and Family Planning, Women's Empowerment, Child Protection in Palangka Raya City includes the integrated communitybased child protection program that has been running and on target, a community-based integrated child protection program is useful and accepted in the City of Palangka Raya, during the implementation of an integrated community-based child protection program there has been a decrease in the number of violence, Resources Implementation of integrated community-based child protection programs both in terms of human resources and budget is still lacking and inadequate, integrated community-based child protection program received a good response from the people of Palangka Raya City, and strategy undertaken by the Population Control and Family Planning Office, Women's Empowerment, Child Protection in Palangka Raya City in implementing a community-based integrated child protection program is to carry out socialization and training activities for activists or cadres of Integrated Community Based Child Protection in the City Government Palangka Raya.
\end{abstract}

\section{Accepted \\ October 2018 \\ Published \\ December 2018}

masyarakat dikarenakan pemenuhan hak-hak anak yang berkaitan dengan perlindungan masih menjadi pekerjaan rumah yang perlu mendapat perhatian karena masih banyak yang belum terpenuhi. Selama ini anak-anak yang

\section{Pentingnya penanganan kekerasan terhadap anak melalui program perlindungan anak terpadu berbasis \\ PENDAHULUAN}


sedang mengalami kasus hukum, baik dalam posisi sebagai korban ataupun pelaku, adalah yang paling rentan dilanggar hak-haknya. Penanganan yang tidak tepat terhadap mereka berpotensi menimbulkan masalah berkepanjangan di kemudian hari (Hasanah \& Rahardjo, 2016).

Perlindungan Anak Terpadu Berbasis masyarakat (PATBM) menjadi unik untuk dikaji karena Kementerian Pemberdayaan Perempuan dan Perlindungan Anak Republik Indonesia melalui Dinas Pengendalian Penduduk Dan Keluarga Berencana, Pemberdayaan Perempuan, Perlindungan Anak Kota Palangka Raya tidak bisa bekerja sendiri sehingga perlu melibatkan masyarakat untuk mendukung program-program perlindungan anak. Masyarakat yang dimaksud adalah masyarakat yang benar-benar memahami kondisi anak. Dengan kata lain masyarakat harus benar-benar paham tentang pertumbuhan dan perkembangan anak serta hak-hak dan kewajiban yang harus dipenuhi (Kementerian Pemberdayaan Perempuan dan Perlindungan Anak Republik Indonesia, 2016).

Perlindungan anak adalah segala kegiatan untuk menjamin dan melindungi anak dan hak-haknya agar dapat hidup, tumbuh, berkembang, dan berpartisipasi, secara optimal sesuai dengan harkat dan martabat kemanusiaan, serta mendapat perlindungan dari tindak pidana dan diskriminasi (Pasal I Angka (2) UndangUndang Nomor 23 Tahun 2002 jo. Undang-Undang Nomor 35 Tahun 2014 tentang Perlindungan Anak). Undang-Undang Nomor 23 Tahun 2002 jo. UndangUndang Nomor 35 Tahun 2014 tentang Perlindungan Anak menegaskan bahwa pertanggungjawaban orang tua, keluarga, masyarakat, pemerintah dan negara merupakan rangkaian kegiatan yang dilaksanakan secara terus-menerus demi terlindunginya hak-hak anak. Rangkaian kegiatan tersebut harus berkelanjutan dan terarah guna menjamin pertumbuhan dan perkembangan anak, baik fisik, mental, spiritual maupun sosial. Tindakan ini dimaksudkan untuk mewujudkan kehidupan terbaik bagi anak sebagai penerus bangsa yang potensial, tangguh, memiliki nasionalisme yang dijiwai oleh akhlak mulia dan nilai Pancasila, serta berkemauan keras menjaga kesatuan dan persatuan bangsa dan negara. Upaya perlindungan anak perlu dilaksanakan sedini mungkin, yakni sejak dari janin dalam kandungan sampai anak berumur 18 tahun (Yustisia, 2016).

Peraturan Daerah Kota Palangka Raya Nomor 17 Tahun 2013 Tentang Perlindungan Anak Dalam Rangka Mewujudkan Kota Layak Anak, menjelaskan anak adalah amanah dan karunia Tuhan Yang Maha Esa, yang dalam dirinya melekat harkat dan martabat sebagai manusia seutuhnya. Demikian juga anak adalah sebagai generasi penerus cita-cita perjuangan bangsa yang memiliki peran strategis dan mempunyai ciri dan sifat khusus yang diharapkan dapat menjamin kelangsungan eksistensi bangsa dan negara di masa depan. Mengingat posisi dan harapan kepada anak sebagai potensi dan masa depan bangsa sehingga anak patut mendapat perhatian mendalam dari semua pihak agar anak dapat tumbuh dan bekembang secara wajar dan sejahtera serta terhindar dari perlakuan dan tindakan yang salah, kekerasan, diskriminasi yang akan merusak perkembangan anak baik fisik, mental maupun sosial anak (Rinaldi \& Andriyus, 2016).

Peraturan Daerah Kota Palangka Raya Nomor 17 Tahun 2013 Tentang Perlindungan Anak Dalam Rangka Mewujudkan Kota Layak Anak, juga menjelaskan anak perlu mendapat kesempatan seluas-luasnya untuk dapat tumbuh dan berkembang secara optimal, baik secara fisik, mental, sosial dan akhlak yang mulia. Sedangkan pada kenyataannya di Kota Palangka Raya masih terdapat banyak anak yang belum terjamin haknya dan terlindungi dari berbagai bentuk kekerasan dan eksploitasi seperti anak korban perdagangan anak, pekerja anak pada industri, dan anak yang dilacurkan, masih hidup terlantar dan tidak mendapat kesempatan memperoleh pendidikan yang memadai, perhatian 
kesehatannya serta pengembangan kreatifitas dan kebahagiaan pada usia anak seperti anak korban tindak kekerasan, anak terlantar, anak jalanan, anak korban seksual, anak korban perdagangan anak, dan anak-anak lainnya yang kurang beruntung (Asmorowati, 2008).

Program PATBM mulai ada sejak tahun 2016, yang didasarkan oleh Undang-Undang Repubik Indonesia Nomor 35 tahun 2014 tentang Perubahan atas UndangUndang Nomor 23 Tahun 2002 tentang Perlindungan Anak, UU RI Nomor 6 Tahun 2014 tentang Desa, Peraturan Daerah Kota Palangka Raya Nomor 17 Tahun 2013 Tentang Perlindungan Anak Dalam Rangka Mewujudkan Kota Layak Anak. Program PATBM pada Dinas Pengendalian Penduduk dan Keluarga Berencana, Pemberdayaan Perempuan, Perlindungan Anak Kota Palangka Raya adalah salah satu program yang harus dilaksanakan karena program tersebut merupakan salah satu bagian indikator menuju Kota layak anak di Kota Palangka Raya. Penerapan program tersebut yaitu dengan melalui bantuan satuan tugas atau aktivis-aktivis yang ada dikelurahan-kelurahan di wilayah Kota Palangka Raya (Hamudy, 20I5).

Program PATBM yaitu gerakan perlindungan anak yang dikelola oleh sekelompok orang yang tinggal di suatu wilayah (desa atau kelurahan) di 34 Provinsi di Indonesia. Melalui PATBM, masyarakat diharapkan mampu mengenali, menelaah, dan mengambil inisiatif untuk mencegah dan memecahkan permasalahan kekerasan terhadap anak yang ada di lingkungannya sendiri. Pengertian dari PATBM yaitu sebuah gerakan dari jaringan atau kelompok warga pada tingkat masyarakat yang bekerja secara terkoordinasi untuk mencapai tujuan perlindungan anak. Program PATBM merupakan inisiatif masyarakat sebagai ujung tombak untuk melakukan upaya-upaya pencegahan dengan membangun kesadaran masyarakat agar terjadi perubahan pemahaman, sikap dan perilaku yang memberikan perlindungan kepada anak. Gerakan tersebut dapat dikelola dengan menggunakan dan mengembangkan fungsi struktur kelembagaan yang sudah ada atau jika diperlukan dengan membangun struktur kelembagaan yang baru. Melalui PATBM, akan dilakukan sejumlah kegiatan seperti penyuluhan, pencegahan, penanganan, dan rehabilitasi terkait isu perlindungan anak. Serta dibutuhkan sinergitas lembaga desa atau perangkat desa, posyandu, sekolah, kader KB, Perlindungan Anak terpadu berbasis masyarakat desa lain, hingga Lembaga Swadaya Masyarakat LSM (Meliyawati, 2016).

\section{METODOLOGI}

Jenis penelitian ini adalah penelitian kualitatif metode yang memfokuskan penelitian dengan menggambarkan fenomena yang sedalam-dalamnya dan menggali informasi sedalam-dalamnya dengan menggunakan kalimat atau kata-kata, dimana peneliti sendiri langsung berada di lapangan. Lokasi penelitian ini di lakukan pada Dinas Pengendalian Penduduk Dan Keluarga Berencana, Pemberdayaan Perempuan, Perlindungan Anak Kota Palangka Raya yang beralamat di jalan Cilik Riwut $\mathrm{Km}$ 5,5 Palangka Raya.

Dalam penelitian ini penulis menetapkan informan yang berkaitan langsung dengan implementasi program perlindungan anak terpadu berbasis masyarakat pada Dinas Pengendalian Penduduk Dan Keluarga Berencana, Pemberdayaan Perempuan, Perlindungan Anak Kota Palangka Raya adalah Dinas Pengendalian Penduduk Dan Keluarga Berencana, Pemberdayaan Perempuan, Perlindungan Anak Kota Palangka Raya, Fasilitator Daerah Program Perlindungan Anak Terpadu Berbasis Masyarakat, Aktivis Program PATBM, Lembaga Swadaya Masyarakat Palangka Raya, Lembaga Perlindungan Anak Indonesia Palangka Raya, serta kalangan akademisi.

Materi yang akan digali melalui wawancara meliputi program-program perlindungan anak terpadu berbasis masyarakat. Sumber data wawancara terdiri dari Dinas Pengendalian Penduduk Dan Keluarga Berencana, Pemberdayaan Perempuan, Perlindungan Anak Kota 
Palangka Raya, Fasilitator Daerah Program Perlindungan Anak Terpadu Berbasis Masyarakat, Lembaga Swadaya Masyarakat Palangka Raya, Lembaga Perlindungan Anak Indonesia Palangka Raya, serta kalangan akademisi. Dalam wawancara disiapkan panduan wawancara untuk mempermudah pengumpulan data. Waktu wawancara tergantung kesiapan informan, bisa pagi, siang, sore. Setiap wawancara menggunakan waktu satu jam. Selain itu juga dilakukan observasi untuk menggali data yang berkaitan dengan program perlindungan anak terpadu berbasis masyarakat. Dalam observasi disiapkan perangkat alat dalam menggali data yang berupa daftar cek, catatan lapangan, jurnal harian, alat perekam elektronik dan format lainnya. Dalam observasi di fokuskan pada Dinas Pengendalian Penduduk Dan Keluarga Berencana, Pemberdayaan Perempuan, Perlindungan Anak Kota Palangka Raya dengan menggunakan waktu selama tiga jam.

Penarikan kesimpulan dan verifikasi adalah berdasarkan data relevan yang di kumpulkan dan di tampilkan tersebut, kemudian di tarik suatu kesimpulan untuk memperoleh hasil akhir penelitian, Sehingga data yang diambil tidak menyimpang dari data yang di peroleh atau dianalisa. Hal ini dilakukan agar hasil penelitian secara konkrit sesuai dengan keadaan yang dilapangan. Dalam melakukan pengujian keabsahan data akan dilakukan empat model/cara pengujian, yaitu credibility, transferability, dependability, dan confirmability.

\section{HASIL DAN PEMBAHASAN}

\section{Isi Kebijakan}

Isi kebijakan mencakup beberapa hal, diantaranya:

I. Kepentingan kelompok sasaran

Kepentingan yang terpengaruhi oleh kebijakan menyangkut sejauh mana kepentingan kelompok sasaran atau target groups termuat dalam isi kebijakan. Kepentingan tersebut berkaitan dengan berbagai kepentingan yang memiliki pengaruh terhadap suatu implementasi kebijakan. Indikator ini memiliki argumen bahwa dalam pelaksanaan sebuah kebijakan pasti melibatkan banyak kepentingan, dan sejauh mana pengaruh yang dibawa oleh kepentingan-kepentingan tersebut terhadap implementasinya.

Sebelum suatu kebijakan diimplementasikan, pelaksana kebijakan harus menyadari bahwa suatu keputusan telah dibuat dan perintah untuk melaksanakannya, Kebijakan yang dikeluarkan haruslah memang merupakan suatu kebutuhan yang dibutuhkan oleh masyarakat dan untuk kepentingan kesejahteraan masyarakat. Sasaran utama kebijakan PATBM adalah anak karena yang akan dilindungi adalah anak. Untuk mewujudkan perlindungan anak tersebut, diperlukan perubahan-perubahan sistemik, tidak saja pada anak-anak, tetapi juga pada lingkungan yang paling berpengaruh terhadap kehidupan anak-anak. Sesuai dengan konteks kegiatan berbasis masyarakat dan tujuan PATBM, maka sasaran utama kegiatan-kegiatan PATBM adalah anak, orang tua, keluarga, dan masyarakat yang ada di wilayah Kota Palangka Raya. Sejauh ini Program perlindungan anak terpadu berbasis masyarakat memang sangat baik dan tepat sasaran, adapun kebijakan-kebijakan selalu mengacu pada sosialiasi dan pencegahan

2. Manfaat yang diterima oleh Kelompok sasaran

Pada poin ini content of policy berupaya untuk menunjukkan atau menjelaskan bahwa dalam suatu kebijakan harus terdapat beberapa jenis manfaat yang menunjukkan dampak positif yang dihasilkan oleh pengimplementasian kebijakan yang hendak dilaksanakan. Dalam konteks hal ini, bahwa pemerintahan yang amanah, berarti pemerintah haruslah menyelesaikan persoalan-persoalan walaupun tidak bisa dikatakan seluruh persoalan, karena keterbatasan diri pemerintah sendiri, untuk kemudian memberdayakan masyarakat atau melalui 
LSM dan organisasi lainnya untuk menyelesaikan persoalan yang muncul dalam masyarakat, dimana upaya intervensi pemerintah haruslah bermanfaat bagi masyarakat secara langsung maupun tidak langsung

Jika dilihat dari aspek bermanfaat atau tidak, maka semakin bermanfaat implementasi kebijakan publik, dengan sendirinya dalam proses implementasi nantinya akan lebih mudah, dalam artian untuk waktu yang tidak begitu lama implementasi kebijakan dilaksanakan serta mudah dalam proses implementasi, sebaliknya bila tidak bermanfaat maka akan sulit dalam proses implementasi lebih lanjut. Kegiatan ini dilaksanakan oleh Dinas Pengendalian Penduduk Dan Keluarga Berencana, Pemberdayaan Perempuan, Perlindungan Anak Kota Palangka Raya, Fasilitator/aktivis PATBM yang ada di Wilayah Kota Palangka Raya. Program PATBM bermanfaat dan diterima di Kota Palangka Raya karena membantu dalam pengawasan dan perlindungan anak dilingkungan sekitar wilayah kelurahan yang ada di Kota Palangka Raya

3. Perubahan yang diinginkan dari sebuah kebijakan Setiap kebijakan mempunyai target yang hendak dan ingin dicapai. Content of Policy yang ingin dijelaskan pada poin ini adalah bahwa seberapa besar perubahan yang hendak atau ingin dicapai melalui suatu implementasi kebijakan harus mempunyai skala yang jelas. Melalui Implementasi Program PATBM pada dinas Pengendalian Penduduk dan Keluarga Berencana, Pemberdayaan Perempuan, Perlindungan Anak Kota Palangka Raya telah terjadi perubahan penurunan angka kekerasan. Penerapan program PATBM yaitu dengan melalui bantuan satuan tugas atau aktivis-aktivis yang ada dikelurahan-kelurahan di wilayah Kota Palangka Raya. Ditingkat Provinsi Kalimantan Tengah Telah terjadi penurunan kasus kekerasan terhadap anak yakni Terhitung sejak Tahun 2013 sebesar 28\%,
Tahun 2014 sebesar $27 \%$, tahun 2015 sebesar $25 \%$, dan di tahun 2016 sebesar 20\%. Ditingkat Kota Palangka Raya Telah terjadi penurunan kasus kekerasan terhadap anak yakni Terhitung sejak Tahun 2013 sebesar 42\%, Tahun 2014 sebesar 33\%, tahun 2016 sebesar $25 \%$, dan di tahun 2017 sebesar $5 \%$.

4. Letak sebuah program sudah tepat

Ketepatan sebuah program merujuk pada nilai atau harga dari tujuan program dan pada kuatnya asumsi yang melandasi tujuan-tujuan tersebut. Melalui program PATBM dapat menurunkan angka kekerasan pada anak hal ini dapat dipahami bahwa program perlindungan anak terpadu berbasis masyarakat adalah suatu inovasi dari pemerintah kemudian memberdayakan masyarakat untuk berpartisipasi langsung dan turut andil dalam menekan angka kekerasan terhadap anak. Program ini dipercaya sudah tepat dan akan sangat bermanfaat dengan keterlibatan masyarakat

5. Program telah menyebutkan implementornya dengan rinci

Dalam menjalankan suatu kebijakan atau program harus didukung dengan adanya pelaksana kebijakan yang kompeten dan kapabel demi keberhasilan suatu kebijakan. Aktivis PATBM di desa/kelurahan Tumbang Rungan dan Menteng yang ada di wilayah Kota Palangka Raya adalah orang-orang yang memiliki kepedulian terhadap isu perlindungan anak serta secara sukarela menyatakan kesediaan untuk menjadi tim kerja yang aktif menggerakan PATBM. Di samping itu, di antara aktivis tersebut diharapkan ada yang memiliki kemampuan untuk merumuskan rencana dan mengelola sumberdaya yang diperlukan untuk pelaksanaan kegiatan perlindungan anak, termasuk mempengaruhi orang untuk berpartisipasi aktif dalam promosi hak anak, mencegah kekerasan, membantu mengarahkan penanganan secara tepat, 
mengelola data dan informasi, serta melakukan monitoring evaluasi kegiatan.

Didalam PATBM di Wilayah Kota Palangka Raya aktivisnya terdiri dari Kader PKK, Karang Taruna, Tokoh Masyarakat (RT dan RW), Tokoh Agama, Tokoh adat, Mantir. Aktivis PATBM dapat berkoordinasi dengan lurah/kepala desa dan aparat pelaksana/kepala urusan kesejahteraan rakyat. Perekrutan awal aktivis PATBM dilakukan oleh fasilitator bekerja sama dengan pemerintah desa/kelurahan, perwakilan tokoh-tokoh masyarakat, perwakilan anak/forum anak setempat, dan perwakilan warga masyarakat.

Fasilitator pengembangan PATBM adalah sesorang relawan yang peduli terhadap isu perlindungan anak dan bersedia diberi tugas oleh Dinas Pengendalian Penduduk Dan Keluarga Berencana, Pemberdayaan Perempuan, Perlindungan Anak Kota Palangka Raya untuk membantu dalam mengembangkan PATBM di desa/kelurahan serta membantu menggalang dukungan dari berbagai pihak. Mereka diutamakan pekerja sosial relawan atau tenaga kesejahteraan sosial relawan yang pernah memiliki pengalaman bekerja/berpraktek dalam pengembangan masyarakat dan perlindungan anak, serta bertempat tinggal di Kota Palangka Raya.

Fasilitator direkrut oleh Dinas Pengendalian Penduduk Dan Keluarga Berencana, Pemberdayaan Perempuan, Perlindungan Anak Kota Palangka Raya, selanjutnya dikukuhkan oleh Kementerian Pemberdayaan Perempuan Perlindungan anak RI. Pada awal pengembangan PATBM, Dinas Pengendalian Penduduk Dan Keluarga Berencana, Pemberdayaan Perempuan, Perlindungan Anak Kota Palangka Raya merekrut satu orang fasilitator yang bertugas memfasilitasi pengembangan PATBM di dua desa.

Kemampuan aktivis maupun fasilitator PATBM harusnya diperkuat melalui pelatihan-pelatihan atau kegiatan pengembangan kapasitas lainnya seperti melalui pelayanan konsultasi dan proses pendampingan oleh fasilitator, penyertaan dalam forum pertemuan/seminar/diskusi yang berkenaan dengan perlindungan anak, pertukaran pengalaman, Implementasi aktivis dan fasilitator terhadap masyarakat, Undang-Undang, batasan-batasan sebagai aktivis dan fasilitator, dan lain sebagainya. Hal tersebut perlu dilakukan karena seperti mereka aktivis dan fasilitator adalah orang-orang yang paling berisiko ketika menjalankan program PATBM tersebut.

6. Program belum didukung sumberdaya yang memadai Dengan adanya penyusunan anggaran yang maksimal usaha-usaha implementasi sebuah program akan lebih banyak berhasil apabila ditunjang oleh kebijaksanaan-kebijaksanaan yang terarah dan dibantu oleh perencanaan yang matang terkait dengan dukungan anggaran yang memadai. Adanya perencanaan yang baik terkait anggaran dapat digunakan sebagai alat untuk merumuskan rencana Dinas Pengendalian Penduduk Dan Keluarga Berencana, Pemberdayaan Perempuan, Perlindungan Anak Kota Palangka Raya dan untuk menjalankan berbagai macam kegiatan kantor secara menyeluruh. Dengan demikian, anggaran merupakan suatu alat manajemen yang dapat digunakan baik untuk keperluan perencanaan sampai pelaksanaan program. Saat ini yang menjadi faktor penghambat Dinas Pengendalian Penduduk Dan Keluarga Berencana, Pemberdayaan Perempuan, Perlindungan Anak Kota Palangka Raya dalam mengimplementasikan Program PATBM Adalah Dana pembinaan yang belum memadai dan kurang.

Salah satu syarat berjalannya suatu organisasi adalah pengaruh dari sumber daya. Sumber daya merupakan hal penting dalam implementasi kebijakan yang baik. Sumber daya manusia adalah faktor utama dalam suatu organisasi. Apapun bentuk 
serta tujuannya, organisasi dibuat berdasarkan berbagai visi untuk kepentingan manusia dan dalam pelaksanaan misinya dikelola dan diurus oleh manusia. Jadi, manusia merupakan faktor strategis yang menentukan sukses dan tidak suksesnya semua kegiatan institusi/organisasi.

Sumber daya manusia yang utama dalam implementasi kebijakan adalah staf atau pegawai. Kegagalan yang sering terjadi dalam implementasi kebijakan, salah satunya disebabkan oleh staf/pegawai yang tidak cukup memadai, mencukupi, ataupun tidak kompeten dalam bidangnya. Penambahan jumlah staf atau implementor saja tidak cukup menyelesaikan persoalan implementasi kebijakan, tetapi diperlukan sebuah kecukupan staf dengan keahlian dan kemampuan yang diperlukan (kompeten dan kapabel) dalam mengimplementasikan kebijakan. Saat ini yang menjadi faktor penghambat Dinas Pengendalian Penduduk Dan Keluarga Berencana, Pemberdayaan Perempuan, Perlindungan Anak Kota Palangka Raya dalam mengimplementasikan Program PATBM adalah masih kurangnya tenaga teknis serta Masih sedikitnya terbentuk satgas PATBM di kelurahan yang ada di wilayah Kota Palangka Raya. Berdasarkan penjelasan diatas bahwa sumber daya Implementasi program perlindungan anak terpadu berbasis masyarakat baik dilihat dari sisi sumber daya manusia dan anggaran masih kurang dan belum memadai.

\section{Lingkungan Implementasi}

Lingkungan Implementasi mencakup beberapa hal, diantaranya:

I. Kekuasaan, kepentingan, dan strategi yang dimiliki para aktor yang terlibat dalam implementasi kebijakan

Dalam suatu kebijakan perlu diperhitungkan pula kekuatan atau kekuasaan, kepentingan, serta strategi yang digunakan oleh para aktor yang terlibat guna memperlancar jalannya pelaksanaan suatu implementasi kebijakan. Strategi yang dilakukan oleh Dinas Pengendalian Penduduk Dan Keluarga Berencana, Pemberdayaan Perempuan, Perlindungan Anak Kota Palangka Raya dalam mengimplementasi program perlindungan anak terpadu berbasis masyarakat adalah dengan melaksanakan kegiatan pelatihan bagi aktivis atau kader PATBM di lingkungan Pemerintah Kota Palangka Raya.

2. Karakteristik institusi dan rezim yang sedang berkuasa

Lingkungan dimana suatu kebijakan tersebut dilaksanakan juga berpengaruh terhadap keberhasilannya, maka pada bagian ini ingin dijelaskan karakteristik dari suatu lembaga yang akan turut mempengaruhi suatu kebijakan. Program PATBM dipengaruhi oleh beberapa lembaga diantaranya Dinas Pengendalian Penduduk dan Keluarga Berencana, Pemberdayaan Perempuan, Perlindungan Anak Kota Palangka Raya, Lembaga Perlindungan Anak Indonesia dan Lembaga Swadaya Masyarakat.

3. Tingkat kepatuhan dan responsivitas Kelompok sasaran

Hal lain yang dirasa penting dalam proses pelaksanaan suatu kebijakan adalah kepatuhan dan respon dari pelaksana, maka yang hendak dijelaskan pada poin ini adalah sejauhmana kepatuhan dan respon dari pelaksana dalam menanggapi suatu kebijakan. Program PATBM dilihat dari responsivitas dan kepatuhan sangat menerima dan terbuka serta bermanfaat di masyarakat yang ada di wilayah Kota Palangka Raya.

Faktor-Faktor Pendukung dan Penghambat Implementasi Program PATBM

Dalam sebuah implementasi program atau kebijakan publik yang notabene program atau kebijakan publik 
tersebut sebenarnya berfungsi untuk kebaikan. Suatu kebijakan program akan menjadi efektif apabila dilaksanakan sesuai dengan ketentuan dan mempunyai manfaat positif bagi masyarakat. Dari data-data yang peneliti kumpulkan selama kegiatan penelitian, dapat disimpulkan beberapa faktor pendukung dan penghambat Implementasi Program PATBM yaitu:

\section{Faktor pendukung}

a. Program PATBM bermanfaat dan diterima di Kota Palangka Raya

PATBM adalah gerakan perlindungan anak yang dikelola oleh sekelompok orang yang tinggal di suatu wilayah (desa atau kelurahan) di 34 Provinsi di Indonesia. Melalui PATBM masyarakat diharapkan mampu mengenali, menelaah, dan mengambil inisiatif untuk mencegah dan memecahkan permasalahan kekerasan terhadap anak yang ada di lingkungannya sendiri. Program perlindungan anak terpadu berbasis masyarakat bermanfaat dan diterima dikota Palangka Raya, karena setiap tahunnya selalu ada kasus yang selalu dilaporkan dan selain itu sosialisasi yang ada di wilayah Kota Palangka Rayapun berjalan dengan baik dan selalu diterima dimasyarakat di Kota Palangka Raya.

b. Program PATBM sudah tepat dalam menekan angka kekerasan terhadap anak

Program PATBM sudah tepat dalam menekan angka kekerasan terhadap anak, hal ini dapat dipahami bahwa program perlindungan anak terpadu berbasis masyarakat adalah suatu inovasi dari pemerintah kemudian memberdayakan masyarakat untuk berpartisipasi langsung dan turut andil dalam menekan angka kekerasan terhadap anak. Program ini dipercaya sudah tepat dan akan sangat bermanfaat dengan keterlibatan masyarakat. c. Telah terjadi perubahan dalam menekan angka kekerasan anak di Kota Palangka Raya

Dengan adanya Program perlindungan anak terpadu berbasis masyarakat telah terjadi perubahan dalam menekan angka kekerasan terhadap anak di Wilayah Kota Palangka Raya. Di tingkat Provinsi Kalimantan Tengah Telah terjadi penurunan kasus kekerasan terhadap anak yakni Terhitung sejak Tahun 2013 sebesar $28 \%$, Tahun 2014 sebesar $27 \%$, tahun 2015 sebesar $25 \%$, dan di tahun 2016 sebesar 20\%. Berdasarkan diagram diatas, Ditingkat Kota Palangka Raya Telah terjadi penurunan kasus kekerasan terhadap anak yakni Terhitung sejak Tahun 2013 sebesar $42 \%$, Tahun 2014 sebesar 33\%, tahun 2016 sebesar $25 \%$, dan di tahun 2017 sebesar $5 \%$.

2. Faktor penghambat

a. Masih kurangnya tenaga teknis Pelatihan PATBM Tenaga teknis merupakan karyawan yang bertugas membantu dalam bidang keteknisan program perlindungan anak terpadu berbasis masyarakat diwilayah Kota Palangka Raya. Berdasarkan wawancara lapangan faktor penghambat dari implementasi program perlindungan anak terpadu berbasis masyarakat adalah kurangnya tenaga teknis untuk pelatihan program perlindungan anak terpadu berbasis masyarakat.

b. Kurangnya kesadaran masyarakat

Kurangnya kesadaran masyarakat dalam hal ini yaitu masih kurang terbukanya masyarakat dengan kejadian di lingkungan yang ada disekitar.

c. Masih sedikitnya satgas PATBM di Kelurahan

Satgas PATBM bertugas untuk membantu pemerintah menjangkau kasus kekerasan terhadap anak menghadapi kasus-kasus kekerasan perempuan dan anak serta 
memberikan pendampingan bagi korban kekerasan terhadap anak. Dalam hal ini faktor penghambat implementasi program perlindungan anak terpadu berbasis masyarakat masih sedikitnya terbentuk satgas PATBM, sehingga untuk penanganan kasus tidak terkoordinasi.

\section{d. Dana pembinaan yang belum memadai}

Sejauh ini sumber dana yang tersedia untuk melaksanakan program PATBM masih Belum optimal, sehingga perlu dicarikan solusi untuk sumber pendanaan lainnya.

\section{KESIMPULAN}

Penelitian ini menghasilkan kesimpulan bahwa implementasi Program PATBM pada Dinas Pengendalian Penduduk dan Keluarga Berencana, Pemberdayaan Perempuan, Perlindungan Anak Kota Palangka Raya mencakup beberapa hal yaitu Program PATBM telah berjalan dan tepat sasaran, Program tersebut bermanfaat dan diterima di Kota Palangka Raya, selama dilaksanakan Program PATBM telah terjadi penurunan angka kekerasan, Sumber daya Implementasi program PATBM baik dilihat dari sisi sumber daya manusia dan anggaran masih kurang dan belum memadai, Program PATBM mendapatkan respon yang baik dari masyarakat Kota Palangka Raya, serta strategi yang dilakukan oleh Dinas Pengendalian Penduduk dan Keluarga Berencana, Pemberdayaan Perempuan, Perlindungan Anak Kota Palangka Raya dalam mengimplementasi program PATBM adalah dengan melaksanakan sosialisasi dan pelatihan bagi aktivis atau kader PATBM dilingkungan Pemerintah Kota Palangka Raya. Perlu upaya dalam mengatasi hambatan implementasi kebijakan, diantaranya meningkatkan kegiatan pelatihan aktivis/kader PATBM di Pemerintah Kota Palangka Raya. Selain itu upaya lain juga perlu untuk mengupas bagaimana Implementasi aktivis tehadap masyarakat, Undang-Undang, serta batasan sebagai aktivis, hal tersebut perlu dikarenakan aktivis adalah orang-orang yang paling berisiko ketika pelaksanaan dilapangan.

\section{REFERENSI}

Asmorowati, S. 2008. Efektivitas Kebijakan Perlindungan Pekerja Anak (Child Labour) dengan Fokus Anak Jalanan di Surabaya. Jurnal Penelitian Dinamika Sosial. 7(I):3 I-44.

Hamudy, M.I.A. 20I5. Pembentukan Kelembagaan Keluarga Berencana di Kabupaten Sukabumi Dan Kota Bitung. Jurnal Bina Praja. 7(I):2I-36.

Hasanah, U. \& Rahardjo, S.T. 2016. Penanganan Kekerasan Anak Berbasis Masyarakat. Share: Social Work Journal. 6(1):80-92.

Kementerian Pemberdayaan Perempuan dan Perlindungan Anak Republik Indonesia. 2016. Pedoman Perlindungan Anak Terpadu Berbasis Masyarakat. Jakarta: Kementerian Pemberdayaan Perempuan dan Perlindungan Anak Republik Indonesia.

Meliyawati. 2016. Peran Keluarga Sekolah Dan Masyarakat Dalam Upaya Pencegahan Kekerasan Seksual Pada Anak di Desa Astanajapura Kecamatan Astanajapura Kabupaten Cirebon. Jurnal Empower: Jurnal Pengembangan Masyarakat Islam. I (I): I-I3.

Peraturan Daerah Kota Palangka Raya Nomor 17 Tahun 2013 Tentang Perlindungan Anak Dalam Rangka Mewujudkan Kota Layak Anak.

Peraturan Pemerintah Nomor 73 Tahun 2005 tentang Kelurahan.

Rinaldi, K. \& Andriyus. 2016. Menelaah Kebijakan Dinas Sosial dan Pemakaman Atas Hak-Hak Anak Di Kota Pekanbaru. Publika: Jurnal Ilmu Administrasi Publik. 2(I):99-I I2.

Undang-Undang Republik Indonesia Nomor 35 tahun 2014 tentang Perubahan atas Undang-Undang Nomor 23 Tahun 2002 tentang Perlindungan Anak.

Undang-Undang Republik Indonesia Nomor 6 Tahun 2014 Tentang Desa.

Yustisia, T.V. 2016. Konsolidasi Undang-Undang Perlindungan Anak. Jakarta: Visimedia. 